\title{
Thyroglossal Duct Cyst
}

National Cancer Institute

\section{Source}

National Cancer Institute. Thyroglossal Duct Cyst. NCI Thesaurus. Code C85189.

A congenital benign cyst arising from the remnants of the thyrog lossal duct. It is usually located in the midline of the neck. 